\title{
POSTMODERNI KOMMUNISMIN JÄLKEEN
}

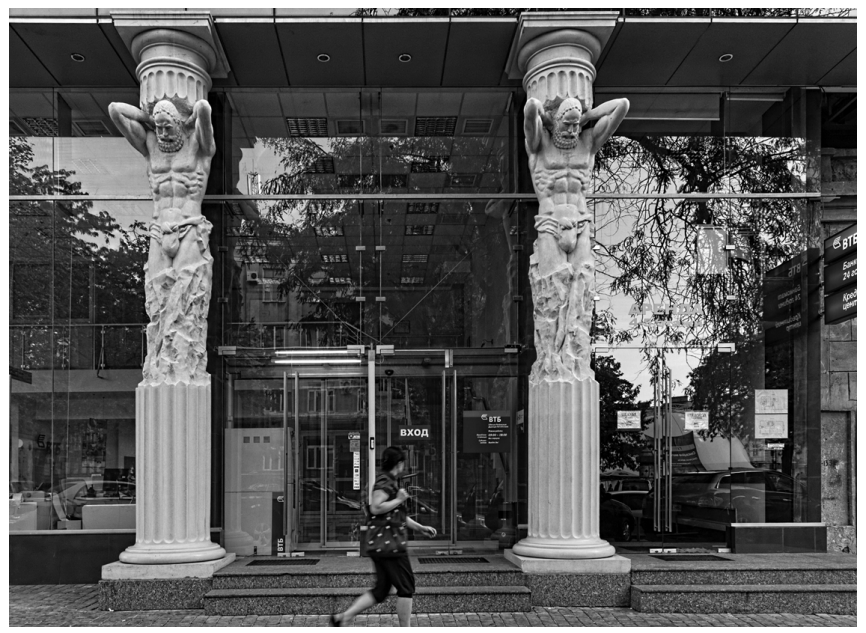

LASIKUITUISET ATLANTTIT KANNATTELEVAT PANKIN JULKIKUVAA ODESSASSA.

VALOKUVA: KIMMO SARJE, 2012.

Odessassa voi kulkea kilometreittäin kauniita, hiljaisia katuja, joita reunustavat paksumuuriset, matalahkot, maalauksellisesti rapistuneet asuintalot. Jalkakäytävillä kasvavien vanhojen plataanien vahvat oksistot kruunaavat katutilan holvimaisella lehvistöllään. Klassista, yksinkertaista, ikuista.

Lähempänä keskustaa katumaasturit röyhkeine keuloineen tunkeutuvat puiden lomaan jalkakäytäville.

Keskustassa on myös näyttämisen ja kerskaamisen Odessa. Se kuuluu kaupungin henkeen aina Potemkinin portaiden ajoista. On erityisrakennuksia, joiden dekoraatioissa ja tyylilainoissa ei ole säästelty.

Odessan oma art nouveau -arkkitehti Lev Vlodek, "maksimalisti”, on koristanut kaupunkia teatraalisilla rakennuksilla. Hänen suunnittelemansa suuri hotelli vuodelta 1904 purettiin ja pystytettiin uudestaan teräsbetonisena kopiona. Sanotaan, että Odessan sorakivi, josta monet rakennukset on tehty, on liian haurasta kestääkseen.

Myös uusvanhaa art nouveauta näkee. Ympyränmuotoista puistoravintolaa somistavat katon reunalla istuvat vedenneitoveistokset ja simpukanmuotoiset suuret ikkunat.

Postkommunistinen Odessa on viehtynyt kulisseihin, ja Las Vegas kajastaa sylttytehtaana. Ironisesta leikistä onkin tullut fyysistä kaupunkitilaa. Ei väliä jos on halpaa, kunhan on näyttävää.

Muutamien uusien liikerakennusten pääsisäänkäyntiä koristavat korkeat ehkä lasikuituiset atlanttit tai karyatidit, jotka peilautuvat lasiseen fasadiin. Myös uuden stadionin arkkitehtuuri leikkii julkisivuissaan violettiin ja pinkkiin sävytetyn klassismin ja peililasin rinnastuksilla. Toisaalla taas sarjakuvahahmot ja klassinen arkkitehtuuri rinnastuvat.

Uudet asuinkerrostalokompleksit ovat kuin scifi-jugendia pyöreine torneineen ja kaarevine parvekkeineen. Pohjakerroksen marketin suuaukoksi on laskeutunut avaruusalus.

Odessa on mukavuudenhaluinen ja pompöösi, nousukasmainen ja ajaton. Oh! 